\title{
MEMBANGUN KARAKTER ANAK USIA SEKOLAH DASAR MELALUI KETERAMPILAN BERBICARA
}

\author{
Yasinta Mahendra *) \\ Yasinta.mahendra2014@gmail.com \\ Pendidikan Guru Sekolah Dasar \\ STKIP Muhammadiyah Kotabumi
}

\begin{abstract}
Primary school age is the age of child growing that is the most important part of life. Children are like a sheet of white paper that will hold, and then save all the scratches that are written on the paper. Likewise, children's memories, what children see will be stored in memory and will be imitated or even made into habits in life; this habit will grow into a character of the child later.

In the Big Indonesian Dictionary, characters are interpreted as behavior or habits. Therefore, character becomes a very important thing to determine how a person behaves. The factors of character growth in child it self cannot be separated from the role of parents and teachers as a major source of the role models for children. Errors in educating students that caused by the teachers can be dangerous for the process of children's mental development. Of course, it will affect the character of the child. One of the bases for educating children is through courage, courage to be honest and courageous to speak up expressing things that become obstacles for children.

Speaking skills are one of the media to build brave characters in elementary school-age children, by raising the ability to speak so that the child's mentality will be trained bravely. Especially, brave in expressing things or opinions that the children have from an early age. Therefore, it is hoped that intelligent, skilled, and brave generations will grow and have a strong character base in elementary school age children.
\end{abstract}

Keywords: Character, Elementary School, Speaking

\section{PENDAHULUAN}

Aspek keterampilan dalam berbahasa meliputi, keterampilan berbicara, keterampilan membaca, keterampilan menyimak, dan keterampilan menulis. Dalam artikel terdahulu yang dipublikasikan di Jurnal kependidikan AlIdarah Vol VIII, UIN Raden Intan Lampung, telah dibahas kaitan keterampilan menulis dalam membentuk karakter peserta didik. Untuk itu dalam artikel kali ini akan dibahas keterkaitan antara keterampilan berbicara dalam menumbuhkan karakter berani pada anak. Keterampilan berbicara adalah salah satu aspek keterampilan berbahasa yang dapat dikuasai dengan baik apabila dilatih secara terus-menerus, hingga akhirnya seseorang 
dikatakan terampil/mahir dalam berbicara. Keterampilan berbicara merupakan bentuk keterampilan yang bersifat produktif karena dapat digunakan untuk menyampaikan ide/gagasan, keinginan, harapan, perasaan, secara langsung kepada pendengar dengan menggunakan bahasa sebagai medianya.

Dalam hal tersebut tidak hanya diperlukan bahasa Indonesia yang baik dan benar, tetapi juga isi pembicaraan agar orang lain bisa menangkap dengan jelas. Ada hal lain yang tidak kalah pentingnya dalam proses berbicara, yaitu keberanian dari dalam diri si pembicara. Sering kali kita melihat seseorang enggan mengemukakan pendapatnya disebabkan takut/grogi berbicara di depan orang lain. Hal tersebut terjadi karena kurangnya kemampuan berbicara dalam diri seseorang sehingga mereka merasa takut untuk berbicara. Hal itu disebabkan juga faktor lemahnya karakter yang dimiliki seseorang, terutama karakter berani. Hal tersebut dapat diatasi dengan memupuk karakter pada anak sedini mungkin agar memiliki karakter kuat dalam diri mereka. Menggali karakter berani pada anak dapat dimulai dengan mengajarkan keterampilan berbicara sejak usia Sekolah Dasar. Selain itu, dalam aspek keterampilan berbicara, anak akan diajarkan dalam memilih kosa kata yang tepat agar bahasa yang digunakan dalam berbicara santun. Penggunaan bahasa Indonesia yang santun bertujuan untuk menumbuhkan nilai rasa dan nilai etika sehingga pendengar akan memberikan perhatian dan tidak merasa tersinggung dengan pembicaraan tersebut (Pranowo, 2012:2). Nilai-nilai yang tumbuh dalam diri anak inilah yang akan membentuk karakter kuat dalam diri anak.

Pada umumnya ketika seseorang berbicara, ia hanya sekadar mengucapkan kata-kata tanpa memerhatikan keterpahaman bagi pendengar, ini berkaitan dengan konteks isi pembicaraan yang sedang dibicarakannya. Hal ini tentu bertentangan dengan pendapat Musaba (2012:5), yang mengemukakan bahwa berbicara bukan hanya sekadar mampu mengemukakan apa yang ingin disampaikan, melainkan juga harus dapat menelaah dan memastikan bahwa apa yang disampaikan saat berbicara dapat diterima oleh pendengar atau lawan bicara. Pada saat berbicara inilah diperlukan karakter berani karena ketika berbicara, diperlukan kontrol emosi dan ekspresi yang tepat ketika berbicara menyampaikan sesuatu dalam suasana sedih, marah, kecewa, senang, dan sebagainya. Apabila kontrol emosi tertutup dengan ketakutan dan kecemasan, itu akan berpengaruh pada penggunaan bahasa dan kosa kata yang dihasilkan. Begitu pun dengan sikap, sikap seseorang ketika berbicara baik di depan umum, dalam forum ilmiah, maupun berbicara dalam situasi santai harus dapat dikontrol dengan 
baik. Jika kontrol emosi diperhatikan dengan baik, akan dihasilkan pembicaraan yang baik pula.

Fauzi (2004:132) mengatakan bahwa berbicara terkait dengan karakter atau kepribadian seseorang. Sejalan denganpendapat tersebut, Afandi (2011:87) mengemukakan bahwa karakter adalah watak, tabiat, akhlak, atau juga kepribadian seseorang yang terbentuk dari hasil internalisasi berbagai kebajikan yang diyakini dan mendasari cara pandang, berpikir, sikap, dan cara bertindak orang tersebut. Karakter atau kepribadian akan tampak pada apa yang dikehendaki, dirasakan, dipikirkan, dibicarakan, dan diperbuatnya. Oleh sebab itu, perilaku yang menunjukkan karakter ketika berbicara perlu diperhatikan agar tercipta hubungan yang baik antara pembicara dan pendengar.

Hingga saat ini, pembentukan atau penanaman karakter di lingkungan pendidikan merupakan topik utama yang sedang disosialisasikan pemerintah agar diintegrasikan pada setiap mata pelajaran yang diajarkan di sekolah. Guru membantu dalam membentuk watak peserta didik dengan cara memberikan keteladanan, cara berbicara atau menyampaikan materi yang baik, toleransi, dan berbagai hal yang terkaitnya (Zulnuraini 2012:1). Pendapat lain diungkapkan oleh Soedarsono (2008:23) yang mengatakan bahwa pembinaan watak atau karakter merupakan tugas utama pendidikan. Pembinaan watak atau karakter melalui penanaman nilai-nilai luhur agama, adat istiadat, atau bahkan yang lahir dari kata hati yang suci dan nurani yang jujur akan menimbulkan etika yang menjadikan manusia menjadi bijaksana karena dapat membedakan perbuatan baik dan perbuatan buruk. Oleh karena itu, penanaman nilai karakter pada anak haruslah dipupuk sedini mungkin agar anak usia sekolah dasar dapat membantuk karakter yang ia miliki sejak dini.

\section{PEMBAHASAN}

Mata pelajaran Bahasa Indonesia sebagai salah satu mata pelajaran yang disajikan dan wajib ada di sekolah dasar (SD). Hal ini dilakukan karena aspek keterampilan berbicara dinilai merupakan aspek yang tepat untuk menanamkan karakter berani berbicara bagi siswa. Hal ini bertujuan agar siswa dapat menyampaikan sejumlah gagasan yang dimilikinya dengan berani dan penuh percaya diri. Namun, tetap dilakukan sesuai dengan norma-norma yang berlaku dalam hal berbicara serta dengan etika yang baik. Dengan mengajarkan kemampuan yang cukup melalui aspek keterampilan berbicara maka diharapkan akan ada banyak karakter yang terbentuk dalam diri siswa SD. Nantinya setelah diberikan keterampilan berbicara, diharapkan siswa akan mampu menerapkan 
karakter serta norma atau aturan-aturan yang telah diperoleh dalam pembelajaran keterampilan berbicara. Hal tersebut diharapkaan akan mereka bawa dan terapkan pada etika berperilaku dan berbicara pada masyarakat.

Nilai karakter yang dapat tumbuh dari keterampilan berbicara, yaitu jujur dalam mengungkapkan keinginan, bertanggung jawab dengan apa yang dibicarakan, berani menyampaikan apa yang menjadi ganjalan dalam diri, percaya diri dalam berbicara di depan khalayak ramai, bernalar logis serta kritis, tetapi tetap santun, serta mampu menghargai orang lain dalam berbicara. Nilai-nilai karakter tersebut diharapkan dapat membentuk objektivitas isi pembicaraan, kualitas isi pembicaraan, sasaran atau arah pembicaraan yang tepat, dan gaya berbicara siswa masing-masing dalam mengemukakan pendapat. Namun, saat ini harapan tersebut belum sesuai dengan kenyataan yang ditemukan dan dirasakan. Artinya, siswa belum sepenuhnya memiliki keterampilan berbicara, jangankan keterampilan berbicara keberanian untuk berbicara pun sangat minim. Hal itu tampak pada proses belajar ketika mahasiwa melakukan presentasi.

Pada level mahasiswa saja masih banyak yang tidak berani berbicara di depan kelas untuk menyampaikan atau mengemukakan pendapat, lalu bagaimana dengan siswa sekolah dasar. Hal ini tentunya masih harus melalui proses penelitian lebih dalam. Berdasarkan pendapat di atas maka dipandang ada korelasinya antara pembelajaran keterampilan berbicara bahasa Indonesia yang mengandung nilai-nilai karakter dengan proses pembentukan karakter siswa sekolah dasar. Berdasarkan sejumlah nilai karakter yang telah dijelaskan oleh Kemendiknas, setidaknya ada beberapa karakter yang muncul dalam keterampilan berbicara di antaranya, yaitu berani dalam berbicara/mengemukakan pendapat di depan umum, jujur dalam berbicara, bertanggung jawab dengan apa yang dibicarakan, bernalar dan berpikir logis. Selain itu juga ada karakter kritis dalam penyampaian pendapat.ingin tahu atau cinta ilmu, santun, disiplin, dan menghargai karya atau prestasi orang lain.

\section{Keterampilan Berbicara}

Berbicara merupakan salah satu aspek keterampilan berbahasa yang perlu dikuasai oleh setiap individu yang digunakan untuk proses komunikasi dalam kehidupan seharihari. Seseorang cenderung lebih memilih berbicara untuk melakukan komunikasi kepada individu lainnya daripada menulis karena komunikasi yang dilakukan secara langsung lewat berbicara akan lebih efektif dibandingkan dengan menulis. Ketrampilan berbicara memegang peranan penting dalam kehidupan sehari-hari. 
Beberapa ahli bahasa telah mendefinisikan pengertian berbicara, di antararanya, yaitu Nurgiyantoro. Nurgiyantoro (2001:276) mengemukakan bahwa berbicara adalah aktivitas berbahasa kedua yang dilakukan manusia dalam kehidupan berbahasa, yaitu setelah aktivitas mendengarkan. Berdasarkan bunyi-bunyi yang didengar itu, kemudian manusia belajar untuk mengucapkan dan akhirnya terampil berbicara. Sejalan dengan itu Tarigan (2008:14) mengatakan bahwa berbicara diartikan sebagai kemampuan mengucapkan bunyi-bunyi artikulasi atau kata-kata untuk mengekspresikan, menyatakan dan menyampaikan pikiran, gagasan, serta perasaan. Jadi, dapat disimpulkan bahwa berbicara merupakan suatu penafsiran tanda-tanda yang didapat dari proses mendengar (audible) dan penafsiran dari apa yang terlihat (visible), lalu kemudian hal ini yang dimanfaatkan oleh otot dan saraf dalam tubuh manusia yang diolah kembali demi memerolah gagasan atau ide-ide yang dihasilkan pikiran.

Berbicara juga merupakan suatu bentuk perilaku manusia yang memanfaatkan faktor-faktor fisik, psikologis, neurologis, semantik, dan linguistik. Selanjutnya berbicara menurut Mulgrave dalam Tarigan (2008:16) adalah suatu alat untuk mengomunikasikan gagasan-gagasan yang disusun serta dikembangkan sesuai dengan kebutuhankebutuhan pendengar atau penyimak. Berbicara merupakan instrumen yang mengungkapkan kepada pendengar secara langsung tentang apa yang dibicarakan lalu kemudian nantinya dapat dilihat apakah pembicara memahami atau tidak, baik bahan pembicaraannya maupun isi pembicaraan nya. Demikian pula dengan pendengar, apakah si pendengar dapat menangkap apa yang dibicarakan pembicara, itu semua bergantung pada gaya pemamparan pembicara tersebut. Oleh karena itu, kemampuan berbicara/berbahasa lisan merupakan dasar utama dari pembentukan karakter bagi siswa SD karena kemampuan berbahasa lisan merupakan gaya ekspresi diri yang sering digunakan oleh setiap anak, merupakan bentuk kemampuan pertama yang biasanya dipelajari anak-anak, merupakan tipe kemampuan berbahasa yang paling umum digunakan. Berdasarkan pengertian berbicara yang telah disampaikan oleh beberapa ahli di atas dapat disimpulkan bahwa berbicara adalah kegiatan/aktivitas mengeluarkan bunyi yang berwujud ungkapan, gagasan, informasi yang mengandung makna tertentu secara lisan.

\section{Hakikat Keterampilan Berbicara}

Keterampilan berbicara hakikatnya merupakan kemampuan memproduksi sistem bunyi berupa artikulasi untuk 
menyampaikan kehendak, keinginan, kebutuhan, perasaan, kepada orang lain. Dalam proses berbicara kelengkapan vokal seseorang merupakan prasyarat alamiah yang dapat memproduksi suatu ragam yang luas dari artikulasi, tekanan, nada, kesenyapan, dan lagu kalimat. Keterampilan berbicara juga didasari oleh kepercayaan diri untuk berbicara secara wajar, jujur, benar, dan bertanggung jawab dengan melenyapkan problem psikis, seperti rasa malu, rendah diri, ketegangan, dan berat lidah (Dalman, 2017:18). Dengan demikian, dapat ditarik simpulan bahwa berbicara itu tidak hanya sekadar pengucapan bunyi atau suara, tetapi juga berbicara merupakan cara untuk mengomunikasikan gagasan sesuai dengan kebutuhan pendengar atau penyimak. Dalam berbicara memiliki ketepatan berbicara antara lain yaitu:

a. Ketepatan dalam pengucapan

Seorang pembicara harus membiasakan diri mengucapkan bunyi bahasa secara tepat. Pengucapan bahasa yang tidak tepat dapat mengalihkan perahatian pendengar, hal tersebut terjadi karena pendengar tidak dapat menangkap dengan jelas apa yang sedang dibicarakan. Dapat dipastikan bahwa pola pengucapan, artikulisi, ekspresi tentu akan selalu berbeda-beda bergantung di mana tempat dan suasana seseorang tersebut berbicara dan setiap orang pasti memilik gaya tersendiri dalam berbicara itu karena karakter yang dimiliki seseorang berbeda. Akan tetapi kalau perbedaan itu terlalu berarti bagi pendengar, sepanjang pembicara masih dapat menyampaikan maksud isi pembicaraanya.

b. Ketepatan intonasi

Ketepatan/kesesuaian intonasi merupakan daya tarik tersendiri dalam berbicara. Sekalipun topik yang dibicarakan tidak menarik, dengan penempatan intonasi yang tepat maka bisa jadi topik yang akan dibicarakan lebih menarik. Sebaliknya jika penyampaiannya datar saja tidak diselipkan intonasi, dapat dipastikan menimbulkan kejenuhan bagi pendenga.. Jika hal itu terjadi, keefektifan dalam berbicara akan berkurang.

c. Pilihan kata (diksi)

Pemilihan kata (diksi) pada saat berbicara juga hendaknya diperhatikan karena dengan diksi yang tepat, jelas, dan bervariasi dapat menjadi daya tarik saat berbicara. Maksud kata jelas adalah kalimat yang dipilih saat berbicara mudah dimengerti oleh pendengar. Pendengar akan lebih cepat mengerti apabila kalimat atau kata yang digunakan bukanlah istilah asing bagi pendengar. Jika diksi yang 
digunakan dalam berbicara sudah tidak asing di telinga pendengar, tentu pembicaraan akan lebih efektif dibandingkan dengan istilah asing.

d. Kelancaran

Jika pada saat berbicara seorang pembicara lancar dalam berbicara, itu suatu keuntungan untuknya. Hal itu memudahkan pendengar menangkap isi pembicaraannya. Seringkali kita mendengar seseorang berbicara terbata-bata, bahkan antara bagian yang terbata-bata tersebut terselip bunyi tertentu yang sangat mengganggu pendengar, misalnya menyelipkan bunyi ee, oo, aa, dan sebagainya. Sebaliknya, pembicara yang terlalu cepat berbicara juga menyulitkan pendengar menangkap pokok pembicarannya. Hal itu terjadi karena kondisi psikis orang terseut terganggu. Hal tersebut bisa terjadi karena grogi atau faktor lelah. Oleh karena itu, ketika ingin memulai berbicra hendaklah menyiapkan mental agar saat berbicara nantinya isi pembicaraan tersebut dapat ditangkap dengan baik oleh pendengar.

\section{Tujuan Keterampilan Berbicara}

Tujuan utama dalam berbicara adalah berkomunikasi agar komunikasi berjalan dengan baik. Seorang pembicara harus memahami makna/isi yang terkandung dalam pembicaraannya. Menurut Tarigan (2008:16), berbicara memiliki tiga tujuan umum, yaitu: 1) memberitahukan, melaporkan (to inform); 2) menjamu, menghibur (to entertain); dan 3) membujuk, mengajak, mendesak, meyakinkan (to persuade).

Menurut Iskandarwassid dalam Sriwahyuni (2013:8), tujuan keterampilan berbicara mencakup pencapaian hal-hal sebagai berikut:

1) Kemudahan Berbicara

2) Kejelasan

3) Bertanggung jawab

4) Membentuk pendengaran kritis

5) Membentuk kebiasaan

Kebiasaan berbicara tidak dapat dicapai tanpa kebiasaan berinteraksi dalam bahasa yang dipelajari atau bahkan dalam bahasa ibu. Dari pendapat ahli di atas, dapat disimpulkan bahwa tujuan berbicara, yaitu sebagai alat untuk memudahkan komunikasi antara pembicara dengan pendengar dalam menyampaikan maksud pembicaraan secara jelas dan bertanggung jawab, serta membentuk karakter kritis dan membentuk kebiasan yang baik.

\section{Fungsi Keterampilan Berbicara}

Secara umum keterampilan berbicara memiliki empat fungsi utama dalam kognitif, yaitu aspek afektif, aspek keterampilan berbicara, dan aspek keterampilan mengelola pembelajaran 
berbicara. Oleh karena itu, sudah selayaknya dalam kegiatan pembelajaran keterampilan berbicara siswa SD dibina dan diarahkan agar dapat memahami dan mendalami teori, konsep, dan generalisasi berbicara serta metodologi dalam pembelajaran berbicara. Dengan kata lain, pengetahuan itu dapat meningkat sejalan dengan tahap pembelajarannya yang semakin ditingkatkan. Pengalaman berbicara di depan orang banyak dapat menjadi salah satu penentu semakin baiknya skill/kemampuan berbicara selanjutnya. Jika diperhatikan di sisi lain, kemampuan keterampilan berbicara juga berpengaruh terhadap sikap yang dihasilkan siswa. Boleh jadi selama ini cara berbicara mereka terhadap orang lain belum menunjukkan sikap negatif. Namun, melalui kegiatan pembelajaran keterampilan berbicara cara berbicara mereka menjadi lebih baik. Keterampilan berbicara juga harus dikemas dengan baik agar siswa menjadi lebih menggemari memahami, menghayati, dan mencintai keterampilan berbicara, serta mereka ingin lebih sering melaksanakan kegiatan pembelajaran keterampilan berbicara. Keterampilan berbicara juga sangat erat kaitannya dengan kehidupan sosial manusia karena setiap individu menjadi bagian dari masyarakat. Sebagai anggota masyarakat sangat tergantung pada penggunaan tutur kata masyarakat setempat, penyampaian gagasan, ide, pemikiran, harapan, dan keinginan disampaikan melaui berbicara.

\section{Karakter dan Proses \\ Pembentukannya}

Jika diperhatikan, kehidupan masyarakat Indonesia telah banyak mengalami perubahan sikap mulai dari nilanilai, moral, budaya, dan agama. Bahkan, mayoritas pelakunya adalah kategori anak dan remaja yang masih duduk di bangku sekolah. Padahal seharusnya mereka bisa menempatkan pendidikan kepribadian yang mereka peroleh dari sekolah untuk hal-hal yang baik dan menerapkan sebagaimana mestinya.

Pendidikan di Indonesia masih dapat dikatakan sedikit lebih maju dibandingkan dengan beberapa tahun lalu. Walaupun belum sama dengan pendidikan di negaranegara maju, sudah sedikit berkembang. Dampak dari era globalisasi yang terjadi saat ini membawa masyarakat Indonesia melupakan pendidikan karakter bangsa yang ditanamkan sejak lahir oleh nenek moyang kita dulu. Padahal jika diperhatikan, pendidikan karakter merupakan suatu pondasi bangsa yang sangat penting dan perlu dimiliki anak-anak sejak dini

Anak-anak merupakan generasi penerus bangsa yang apabila dididik dengan cara yang bijaksana akan menghasilkan produk anak bangsa yang berkarakter dan 
berjiwa besar. Untuk membentuk karakter anak bangsa yang baik, pendidikan karakter akan membentuk karakter baik pada diri anak. Pendidikan adalah usaha yang dilakukan orang dewasa dalam pergaulannya dengan anak-anak untuk membimbing perkembangan jasmani dan rohaninya ke arah kedewasaan agar menghasilkan pribadi yang lebih baik atau dengan kata lain pendidikan adalah bimbingan yang diberikan dengan sengaja oleh orang dewasa kepada anak-anak dalam pertumbuhannya baik jasmani maupun rohani agar berguna bagi diri sendiri dan masyarakat di lingkungan tempat tinggal mereka.

Selanjutnya pendidikan menurut John Dewey dalam Muslih (2011:45) adalah proses pembentukan kecakapan fundamental secara intelektual dan emosional ke arah alam dan sesama manusia. Tujuan pendidikan dalam hal ini agar generasi muda sebagai penerus generasi tua dapat menghayati, memahami, mengamalkan nilai-nilai atau norma-norma tersebut dengan cara mewariskan segala pengalaman, pengetahuan, kemampuan dan keterampilan yang melatarbelakangi nilainilai dan norma-norma hidup dan kehidupan..

Dari pendapat di atas dapat disimpulkan bahwa pendidikan adalah landasan utama membangun karakter, yang secara implisit mengandung arti membangun sifat atau pola perilaku yang didasari atau berkaitan dengan dimensi moral yang positif atau yang baik, bukan yang negatif atau yang buruk. Dalam upaya membentuk karakter anak, harus disesuaikan dengan dunia anak tersebut, maksudnya adalah harus selaras atau seimbang dengan tahap-tahap pertumbuhan dan perkembangan anak.

Karakter diibaratkan sebagai pahatan balok besi apabila balok besi dipahat dengan penuh kehati-hatian akan menjadi sebuah karya besar yang sangat mahal dan mengagumkan. Hal itu sama halnya dengan karakter anak apabila kita mengarahkan dan menbentuk karakter pada anak dengan penuh kehati-hatian dan dengan cara yang tepat, akan dihasilkan karakter anak yang baik pula. Oleh karena itu, karakter merupakan kualitas atas kekuatan mental atau moral, akhlak atau budi pekerti seseorang yang menjadi kepribadian khusus sebagai pendorong dan penggerak serta membedakannya individu yang satu dengan individu lainnya.

Dalam upaya membentuk karakter anak, maka kita harus bisa membedakan dalam rentang usia berapa anak tersebut, agar kita dapat menyesuaikandengan dunia anak tersebut pendidikan karakter apa yang selayaknya kita berikan. Hal itu berkaitan dengan pertumbuhan dan perkembangan anak tersebut nantinya. Melalui pendidikan di lingkungan keluarga, sekolah, dan 
lingkungan sosial anak, seseorang dapat mengetahui dan mengembangkan karakter apa yang anak miliki dan karakter apa yang cocok untuk diberikan pada anak. Pendidikan yang diajarkan oleh guru di sekolah merupakan proses pembentukan karakter anak, dari sifat anak yang kurang baik menjadi yang lebih baik. Dengan demikian, di usia SD, anak harus selalu dikontrol dan diawasi dengan baik dan diharapkan nantinya pendidikan yang diperoleh anak di sekolah dapat diterapkan serta diaplikasikan dengan baik dan benar dalam lingkungan bermasyarakat.

Unsur terpenting dalam pembentukan karakter adalah pikiran, karena di dalam pikiran terdapat seluruh program yang terbentuk dari pengalaman hidup individu tersebut. Program ini kemudian membentuk sistem kepercayaan yang akhirnya dapat membentuk dan mempengaruhi pola berpikir dan dapat mempengaruhi perilaku individu. Jika program yang tertanam tersebut sesuai dengan prinsip-prinsip kebenaran universal, perilakunya berjalan selaras dengan hukum alam. Hasilnya, perilaku tersebut membawa ketenangan dan kebahagiaan. Sebaliknya, jika program tersebut tidak sesuai dengan prinsip-prinsip hukum universal, perilakunya membawa kerusakan dan menghasilkan penderitaan. Oleh karena itu, pikiran harus mendapatkan perhatian serius.

\section{Keterampilan berbicara dengan pembentukan Karakter}

Seperti yang sudah dijelaskan di atas bahwa unsur terpenting dalam pembentukan karakter adalah pikiran karena di dalam pikiran terdapat seluruh program yang terbentuk dari pengalaman hidup individu tersebut. Program ini kemudian membentuk sistem kepercayaan yang akhirnya dapat membentuk dan mempengaruhi pola berpikir dan dapat mempengaruhi perilaku individu. Jika program yang tertanam tersebut sesuai dengan prinsip-prinsip kebenaran universal, perilakunya berjalan selaras dengan hukum alam. Hasilnya, perilaku tersebut membawa ketenangan dan kebahagiaan. Sebaliknya, jika program tersebut tidak sesuai dengan prinsip-prinsip hukum universal, perilakunya membawa kerusakan dan menghasilkan penderitaan. Oleh karena itu, pikiran harus mendapatkan perhatian serius.

Dalam hal ini keterampilan berbicara berperan sebagai pemicu lahirnya karakterkarakter baru yang bersifat positif dalam diri anak usia SD. Dengan menerapkan keterampilan berbicara dalam diri anak maka akan tumbuh karakter yang bersifat membangun salah satunya adalah berani, berani dalam hal mengungkapkan apa yang menjadi pendapat serta keinginan dalam diri anak. Hal lain yang timbul karena pembelajaran keterampilan berbicara terdapat keberagaman prilaku dan sikap 
siswa pada saat proses pembelajaran, di antaranya siswa yang aktif berinteraksi. Jika sebelum mengenal keterampilan berbicara siswa yang umumnya aktif selalu siswa yang sama, setelah memiliki bekal keterampilan berbicara semua siwa aktif dan antusias mengemukakan pendapat mereka masing-masing. Hal ini terjadi karena sebelum adanya pelajaran keterampilan berbicara anak memiliki rasa malu, segan, ragu-ragu, setuju, tidak peduli, marah atau tersinggung sehingga mereka tidak berani berbicara mengemukakan pendapat mereka di depan teman-temannya.

Perilaku atau sikap-sikap siswa yang muncul pada saat berlangsungnya proses pembelajaran keterampilan berbicara bahasa Indonesia tersebut merupakan perwujudan dari nilai-nilai karakter. Kemunculan nilai-nilai karakter tersebut juga dapat ditemukan pada saat siswa berada di rumah hasil penanaman karakter oleh orang tua. Para orang tua juga menanamkan karakter anak melalui bahasa, seperti kejujuran, tanggung jawab, keberanian, saling menghormati, dan sebagainya Secara garis besar dapat ditarik simpulan bahwa ada kaitan erat antara pembelajaran keterampilan berbicara dan pembentukan karakter anak usia SD. Dengann demikian, pembelajaran tersebut harus dilatih secara terus-menerus dan berkelanjutan kepada anak dengan tujuan untuk melatih siswa terampil berbicara dengan bahasa Indonesia dan memiliki karakter. Tanpa latihan yang berkelanjutan tidak mungkin dapat diperoleh hasil pembelajaran yang membuat siswa berani dan mampu berbicara dengan bahasa Indonesia di depan orang banyak. Siswa secara terus-menerus dilatih untuk terampil memberikan pertanyaan dan menjawab pertanyaan dengan santun, berkarakter, logis, dan efektif serta bertanggung jawab.

\section{SIMPULAN}

Berdasarkan pemaparan di atas dapat disimpulkan bahwa pendidikan adalah usaha yang dilakukan oleh orang dewasa dalam pergaulannya dengan anak-anak untuk membimbing perkembangan jasmani dan rohaninya kearah kedewasaan agar berguna bagi diri sendiri dan masyarakatnya. Tujuan mempelajari keterampilan berbicara, yaitu membentuk karakter anak sedini mungkin. Hal itu sejalan dengan tujuan pemerintah untuk mewujudkan visi pembangunan nasional, yaitu mewujudkan masyarakat yang berakhlak mulia, bermoral, beretika, berkarakter, berbudaya, dan beradab berdasarkan falsafah Pancasila. Hal ini sekaligus menjadi upaya untuk mendukung perwujudan cita-cita sebagaimana diamanatkan dalam Pancasila dan Pembukaan UUD 1945. Untuk membentuk karakter pada anak dibutuhkan suatu proses, tidak dengan cara yang instan. Proses 
tersebut, yaitu dengan cara pengenalan keterampilan berbicara sehingga dapat terhadap berbicara, pemahaman terhadap tumbuh menjadi karakter yang kuat dalam berbicara, serta sampai pada penerapan diri anak usia SD.

\section{DAFTAR RUJUKAN}

Afandi, Rifki. 2011. Intergrasi Pendidikan Karakter dalam Pendidikan IPS di SD. Jurnal Pedagogia, Vol. 1, No. 1 Desember 2011. Sidoarjo: UNMUH.

Fauzi, Ahmad H. 2004. Psikologi Umum. Bandung: Pustaka Setia.

Muslih, Mansur. 2011. Menjawab Tantangan Krisis Multidimensional. Jakarta: Bumi Aksara

Musaba, Zulkifli. 2012. Terampil Berbicara: Teori dan Pedoman Penerapannya.

Yogyakarta: CV. Aswaja Pressindo.

Nurgiyantoro, Burhan.2001. Penilaian dalam Pengajaran Bahasa dan Sastra Indonesia. Yogyakarta: BPFE.

Pranowo. 2012. Berbahasa secara Santun. Yogyakarta: Pustaka Pelajar.

Sudarsono. 2008. Kenakalan Remaja. Jakarta: Rineka Cipta

Tarigan, Guntur. 2008. Pengembangan Keterampilan Berbicara. Jakarta: Depdikbud.

. 2012. Konsep, Implementasi dan Pengembangannya di Sekolah Dasar di Kota Palu. Jurnal Dikdas No.1, Vol.1, September 2012. Palu: UNTAD. 